ORNL-6913

\title{
TOTAL EFFECTIVE DOSE EQUIVALENT ASSOCIATED WITH FIXED URANIUM SURFACE CONTAMINATION
}

\author{
J. S. Bogard \\ R. N. Hamm \\ J. C. Ashley \\ J. E. Turner \\ C. A. England \\ D. E. Swenson \\ K. S. Brown
}

\section{RECEIVED \\ APR 17 1997 \\ OSTI}


This report has been reproduced directly from the best available copy.

Available to DOE and DOE contractors from the Office of Scientific and Technical Information, P. O. Box 62, Oak Ridge, TN 37831; prices available from (423) 576-8401, FTS 626-8401.

Available to the public from the National Technical Information Service, U.S. Department of Commerce, 5285 Port Royal Road, Springfield. VA 22161.

This report was prepared as an account of work sponsored by an agency of the United States Government. Neither the United States Government nor any agency thereof, nor any of their employees, makes any warranty, express or implied, or assumes any legal liability or responsibility for the accuracy, completeness, or usefulness of any information, apparatus, product, or process disclosed, or represents that its use would not infringe privately owned rights. Reference herein to any specific commercial product, process, or service by trade name, trademark, manufacturer, or otherwise, does not necessarily constitute or imply its endorsement, recommendation, or favoring by the United States Government or any agency thereof. The views and opinions of authors expressed herein do not necessarily state or reflect those of the United States Government of any agency thereof. 


\section{DISCLAIMER}

Portions of this document may be illegible electronic image products. Images are produced from the best available original document. 
Assessment Technology Section

Health Sciences Research Division

\title{
TOTAL EFFECTIVE DOSE EQUIVALENT ASSOCIATED WITH FIXED URANIUM SURFACE CONTAMINATION
}
J. S. Bogard
R. N. Hamm
J. C. Ashley
J. E. Turner
C. A. England
D. E. Swenson
K. S. Brown

Report Issued - April 1997

\author{
Prepared by the \\ OAK RIDGE NATIONAL LABORATORY \\ Oak Ridge, Tennessee 37831-6285 \\ managed by \\ LOCKHEED MARTIN ENERGY RESEARCH CORP. \\ for the \\ U. S. DEPARTMENT OF ENERGY \\ under contract number DE-AC05-96OR22464
}





\section{CONTENTS}

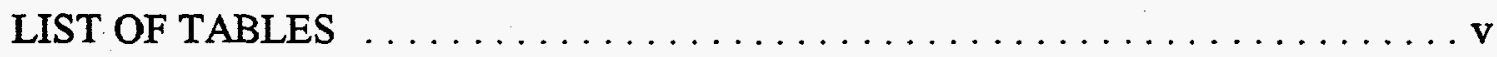

ACKNOWLEDGMENTS $\ldots \ldots \ldots \ldots \ldots \ldots \ldots \ldots \ldots \ldots \ldots \ldots \ldots$ vii

ABSTRACT $\ldots \ldots \ldots \ldots \ldots \ldots \ldots \ldots \ldots \ldots \ldots \ldots \ldots \ldots \ldots$

REQUIREMENTS $\ldots \ldots \ldots \ldots \ldots \ldots \ldots \ldots \ldots \ldots \ldots \ldots \ldots$

EXTERNAL DOSE RATES FROM URANIUM-CONTAMINATED

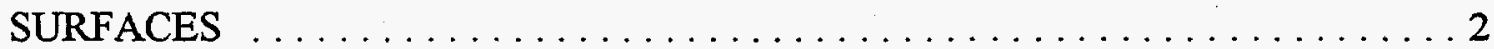

INTERNAL DOSE RATES FROM URANIUM-CONTAMINATED

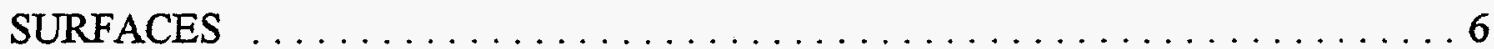

CONTAMINATION GUIDELINE $\ldots \ldots \ldots \ldots \ldots \ldots \ldots \ldots \ldots$

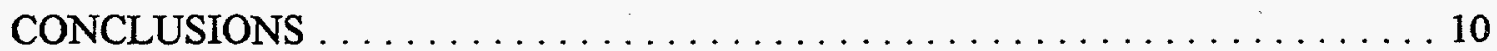

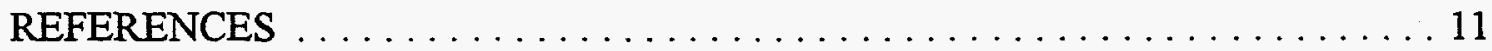





\section{LIST OF TABLES}

1 Committed effective dose equivalents and external dose rate factors $\ldots \ldots \ldots 4$

2 Relative total activities of D-38 isotopes $\ldots \ldots \ldots \ldots \ldots \ldots \ldots \ldots \ldots \ldots \ldots \ldots$

3 Relative total activities of Oralloy isotopes $\ldots \ldots \ldots \ldots \ldots \ldots$

4 Fixed-contamination action levels for D-38 and Oralloy $\ldots \ldots \ldots \ldots$ 



\section{ACKNOWLEDGMENTS}

The authors wish to acknowledge support provided by G. T. Eagle and J. H. Barker of the Y-12 Plant Radiological Control organization for completion of this report. 


\begin{abstract}
This report provides the technical basis for establishing a uranium fixed-contomination action level, a fixed uranium surface contamination level exceeding the total radioactivity values of Appendix D of Title 10, Code of Federal Regulations, Part 835 (10CFR835), but below which the monitoring, posting, and control requirements for Radiological Areas are not required for the area of the contamination. An area of fixed uranium contamination between $1,000 \mathrm{dpm} / 100 \mathrm{~cm}^{2}$ and that level corresponding to an annual total effective dose equivalent (TEDE) of 100 mrem requires only routine monitoring, posting to alert personnel of the contamination, and administrative control. The more extensive requirements for monitoring, posting, and control designated by 10CFR835 for Radiological Areas do not have to be applied for these intermediate fixed-contamination levels.

Fixed uranium contamination with a removable component at the $1,000 \mathrm{dpm} / 100 \mathrm{~cm}^{2}$ limit for a Radiological Area is used as the basis for establishing the fixed-contamination action level for uranium. The annual limit (for purposes of determining the action level) of dose equivalent received from sources external to the body is the difference between 100 mrem TEDE and the committed effective dose equivalent. The committed effective dose equivalent, derived from information in Federal Guidance Report 11, for exposure over a work year to removable surface contamination of $1,000 \mathrm{dpm} / 100 \mathrm{~cm}^{2}$ is $11 \mathrm{mrem}$ for depleted uranium (D-38) and 13 mrem for highly enriched uranium (Oralloy). External exposure rates of $5.1 \times 10^{-2} \mathrm{mrem} / \mathrm{h}$ for D-38 and $4.9 \times 10^{-2} \mathrm{mrem} / \mathrm{h}$ for Oralloy, combined with committed effective dose equivalents from the removable contamination, correspond to a 100-mrem annual TEDE. Effective dose equivalent rates from unit activities of contamination for external exposure to Reference Man standing on the contaminated surface, derived from information in Federal Guidance Report 12, are $1.5 \times 10^{-8} \mathrm{mrem} / \mathrm{h}$ per $\mathrm{dpm} / 100 \mathrm{~cm}^{2}$ for D-38 and $6.5 \times 10^{-9} \mathrm{mrem} / \mathrm{h}$ per $\mathrm{dpm} / 100 \mathrm{~cm}^{2}$ for Oralloy. Values for fixed uranium surface contamination, with a removable contamination component up to $1,000 \mathrm{dpm} / 100 \mathrm{~cm}^{2}$, that correspond to an annual TEDE of $100 \mathrm{mrem}$ are, therefore, $3.4 \times 10^{6} \mathrm{dpm} / 100 \mathrm{~cm}^{2}$ for D-38 and $7.5 \times 10^{6} \mathrm{dpm} / 100 \mathrm{~cm}^{2}$ for Oralloy.
\end{abstract}

A uranium fixed-contamination action level of $3.4 \times 10^{6} \mathrm{dpm} / 100 \mathrm{~cm}^{2}$ is suggested if a single action level is desired or if the uranium isotopic ratios are not known. This is the fixed contamination level below which only routine monitoring, posting to alert personnel of the contamination, and administrative control are required, rather than the more extensive requirements for monitoring, posting, and control designated by 10CFR835 for Radiological Areas. 


\section{TOTAL EFFECTIVE DOSE EQUIVALENT ASSOCIATED WITH FIXED URANIUM SURFACE CONTAMINATION}

This report provides the technical basis for establishing a uranium fixed-contamination action level, a fixed uranium surface contamination level exceeding the total radioactivity values of Appendix D, Title 10, Code of Federal Regulations, Part 835 (10CFR835), but below which the monitoring, posting, and control requirements for Radiological Areas are not required. Both internal and external exposure implications are explored for fixed contamination, with a removable contamination component up to the level for uranium specified in Appendix D of 10CFR835.

\section{REQUIREMENTS}

The level of access control and posting required by 10CFR 835 is greatly reduced, for fixed contamination with no significant external dose potential, over that required either for removable contamination or for fixed contamination with an elevated external dose rate. Parts (d) and (e) of 10CFR835, Section 835.404, "Radioactive Contamination Control and Monitoring," state:

"(d) Areas with fixed contamination exceeding the total radioactivity values specified in Appendix D of this part may be located outside of radiological areas provided the following conditions are met:

(1) Removable contamination levels are below the levels specified in Appendix D of this part;

(2) Unrestricted access to the area is not likely to cause any individual to receive a total effective dose equivalent in excess of $0.1 \mathrm{rem}$ $(0.001$ sievert $)$ in a year;

(3) The area is routinely monitored;

(4) The area is clearly marked to alert personnel of the contaminated status;

(5) Appropriate administrative procedures are established and exercised to maintain control of these areas; and

(6) Dose rates do not exceed levels which would require posting in accordance with $\S 835.603$. 
(e) Entry control pursuant to $\$ 835.501$ and posting pursuant to $\$ 835.603$ are not required for areas with fixed contamination meeting the conditions of $\S 835.404(\mathrm{~d})$."

Radioactivity values for uranium specified in 10CFR835 Appendix D are $1,000 \mathrm{dpm} / 100 \mathrm{~cm}^{2}$ (removable) and $5,000 \mathrm{dpm} / 100 \mathrm{~cm}^{2}$ (fixed). Radiological areas are defined in $\$ 835.603$, which specifies dose rates from the source of radiation which determines the presence of a Radiation Area $(>5 \mathrm{mrem} / \mathrm{h}$ at $30 \mathrm{~cm})$, High Radiation Area $(>100 \mathrm{mrem} / \mathrm{h}$ at $30 \mathrm{~cm})$, or Very High Radiation Area $(500 \mathrm{rad} / \mathrm{h}$ at $1 \mathrm{~m})$. The $0.1-\mathrm{rem}$ (100 mrem) annual total effective dose equivalent (TEDE) specified in Part (d)(2) above refers to the annual dose equivalent above which workers who are likely to receive such a dose must participate in a personnel monitoring program [10CFR835, §835.402(a)(1)(i)].

The dose rate corresponding to a 100 -mrem annual dose is approximately $57 \mu \mathrm{rem} / \mathrm{h}$ (see the section entitled Contamination Guideline for the basis of this value). This dose rate is significantly lower than that which defines a Radiation Area and is, therefore, the limiting value for this analysis. An area of fixed uranium contamination between $1,000 \mathrm{dpm} / 100 \mathrm{~cm}^{2}$ and that contamination level corresponding to an annual TEDE of $100 \mathrm{mrem}$ requires only routine monitoring, posting to alert personnel of the contamination, and administrative control. The more extensive requirements for monitoring, posting, and control designated by 10CFR835 for Radiological Areas do not have to be applied for these intermediate fixedcontamination levels.

The TEDE is defined in 10CFR835 as "the sum of the effective dose equivalent (for external exposures) and the committed effective dose equivalent (for internal exposures)." Therefore, the analysis of dose from uranium contamination must include an evaluation of both internal and external exposures.

\section{EXTERNAL DOSE RATES FROM URANIUM-CONTAMINATED SURFACES}

Estimates of external dose rates from contaminated surfaces can be derived from information contained in Federal Guidance Report 12 [FGR 12], which includes factors for dose equivalent and effective dose equivalent rates from exposure to radionuclides distributed on surfaces, in bulk soil, in water, and in a semi-infinite cloud. These factors are also available in a computer program, DFEXT $v .2 .3^{1}$, which is available from the authors of FGR 12.

Dose factors for integrated exposure to radionuclides on a surface are derived using conventions of ICRP Publication 26 [ICRP 26]. The effective dose equivalent per integrated exposure $h_{\mathrm{E}}$ is given by

${ }^{1}$ DFEXT v. 2.3, A Code to Preview the Dosimetric Data of Federal Guidance Report 12, (O 1994 by K. F. Eckerman. 


$$
h_{\mathrm{E}}=\sum w_{\mathrm{T}} h_{\mathrm{T}},
$$

where $h_{\mathrm{T}}$ is the equivalent dose $H_{\mathrm{T}}$ in tissue $\mathrm{T}$ per unit integrated exposure, and $w_{T}$ is the tissue weighting factor. An infinite plane source is assumed, with Reference Man standing on the air/ground interface. The dose factors include an estimate of bremsstrahlung contribution.

Table 1 provides a summary of effective dose equivalent per integrated exposure $\left(h_{\mathrm{E}}\right.$ in units of mrem $/ \mathrm{h}$ per $\mu \mathrm{Ci} / \mathrm{cm}^{2}$ ) for the uranium isotopes commonly encountered at the Y-12 Plant, Oak Ridge, Tennessee, and their radioactive progeny. The radioactive decay chain of each isotope is followed until a daughter radionuclide with a long (in human terms) half-life is encountered, effectively ending the chain. Progeny with short radiological halflives generated to this point are assumed to be in secular equilibrium with the parent, but the chain-ending daughter and all subsequent progeny are considered to have no appreciable activity for purposes of this evaluation. Two uranium isotopic mixtures are commonly encountered at the Y-12 Plant: Depleted uranium (D-38) and highly enriched uranium (Oralloy). Each of these mixtures is produced as the result of gaseous diffusion of refined natural uranium ${ }^{1}$ (as uranium hexafluoride) through capillary systems that selectively pass the lighter ${ }^{234} U$ and ${ }^{235} U$, enriching the diffused gases in these isotopes and separating them from the heavier ${ }^{238} \mathrm{U}$. Extremes of isotopic composition for uranium enriched or depleted in ${ }^{234} \mathrm{U}^{235} \mathrm{U}$ are considered below.

Depleted uranium is a mixture of isotopes found in natural uranium after removal of ${ }^{235} \mathrm{U}$ and ${ }^{234} \mathrm{U}$ in the gaseous diffusion process. (The ${ }^{234} \mathrm{U}$ isotope is present in the ore in secular equilibrium with ${ }^{238} \mathrm{U}$ and is carried up the diffusion cascade because its mass is close to that of ${ }^{235} \mathrm{U}$.) The isotopic mass distribution in D-38 is approximately $99.75 \%{ }^{238} \mathrm{U}$, $0.25 \%{ }^{235} \mathrm{U}$, and $0.0005 \%{ }^{234} \mathrm{U}$ [EGG-2530, Table 2-1]. Relative activities for each isotope in D-38 are shown in Table 2. The external dose rate factor for surfaces contaminated with $D-38$ is the activity-weighted sum of factors for ${ }^{234} U,{ }^{235} \mathrm{U}$ (with its short-half-life daughter, ${ }^{231} \mathrm{Th}$ ), and for ${ }^{238} \mathrm{U}$ (along with its short-half-life progeny, ${ }^{234} \mathrm{Th}$ and ${ }^{234 \mathrm{~m}} \mathrm{~Pa}$ ). The resulting value of $h_{\mathrm{E}}$ for D-38 is $3.32 \mathrm{mrem} / \mathrm{h}$ per $\mu \mathrm{Ci} / \mathrm{cm}^{2}$ :

${ }^{1}$ Uranium occurring naturally in ores contains approximately (by weight) $99.274 \%$ ${ }^{238} \mathrm{U}, 0.720 \%{ }^{235} \mathrm{U}$, and $0.006 \%{ }^{234} \mathrm{U}$. The activity of ${ }^{234} \mathrm{U}$ is nominally the same as that of the parent ${ }^{238} \mathrm{U}$. 
Table 1. Committed effective dose equivalents and external dose rate factors ${ }^{a}$

\begin{tabular}{|c|c|c|c|}
\hline $\begin{array}{l}{ }^{238} \mathrm{U} \text { and } \\
\text { progeny }\end{array}$ & $T_{1 / 2}$ & $\begin{array}{c}h_{\mathrm{E}} \\
\left(\mathrm{mrem} \mathrm{cc^{2 }} \mu \mathrm{Ci}^{-1} \mathrm{~h}^{-1}\right) \\
\end{array}$ & $\begin{array}{c}h_{\mathrm{E}, 50} \\
(\mathrm{mrem} / \mu \mathrm{Ci}) \\
\end{array}$ \\
\hline${ }^{238} \mathrm{U}$ & $4.5 \times 10^{9} \mathrm{y}$ & 0.07 & $1.18 \times 10^{5}$ \\
\hline${ }^{234} \mathrm{Th}$ & $24 \mathrm{~d}$ & 1.11 & $3.50 \times 10^{1}$ \\
\hline${ }^{234 m} \mathrm{~Pa}$ & $1.2 \mathrm{~min}$ & 2.04 & (Not given) \\
\hline${ }^{234} \mathrm{U}$ & $2.5 \times 10^{5} \mathrm{y}$ & -- & -- \\
\hline Total & & 3.22 & $1.18 \times 10^{5}$ \\
\hline $\begin{array}{l}{ }^{235} \mathrm{U} \text { and } \\
\text { progeny }\end{array}$ & $T_{1 / 2}$ & $\begin{array}{c}\mathrm{h}_{\mathrm{E}} \\
\left(\mathrm{mrem} \mathrm{cm}{ }^{2} \mu \mathrm{Ci}^{-1} \mathrm{~h}^{-1}\right)\end{array}$ & $\begin{array}{c}h_{\mathrm{E}, 50} \\
(\mathrm{mrem} / \mu \mathrm{Ci}) \\
\end{array}$ \\
\hline${ }^{235} \mathrm{U}$ & $7.0 \times 10^{8} y$ & 19.7 & $1.23 \times 10^{5}$ \\
\hline${ }^{231} \mathrm{Th}$ & $25 \mathrm{~h}$ & 2.5 & $8.77 \times 10^{-1}$ \\
\hline${ }^{231} \mathrm{~Pa}$ & $3.3 \times 10^{4} \mathrm{y}$ & - & -- \\
\hline Total & & 22.2 & $1.23 \times 10^{5}$ \\
\hline $\begin{array}{l}{ }^{234} \mathrm{U} \text { and } \\
\text { progeny }\end{array}$ & $T_{1 / 2}$ & $\begin{array}{c}\mathrm{h}_{\mathrm{E}} \\
\left.\text { (mrem cm } \mathrm{cm}^{2} \mu \mathrm{Ci}^{-1} \mathrm{~h}^{-1}\right)\end{array}$ & $\begin{array}{c}\begin{array}{c}h_{\mathrm{E}, 50} \\
(\mathrm{mrem} / \mu \mathrm{Ci})\end{array} \\
\end{array}$ \\
\hline${ }^{234} \mathrm{U}$ & $2.5 \times 10^{5} \mathrm{y}$ & 0.10 & $1.33 \times 10^{5}$ \\
\hline${ }^{230} \mathrm{Th}$ & $7.7 \times 10^{4} y$ & - & - \\
\hline Total & & 0.10 & $1.33 \times 10^{5}$ \\
\hline
\end{tabular}

${ }^{a}$ Committed effective dose equivalent $h_{\mathrm{E}, 50}$ per unit intake from Federal Guidance Report 11 and external dose rate factors $h_{\mathrm{E}}$ for uranium-contaminated surfaces from Federal Guidance Report 12. Each isotope of naturally occurring uranium, along with its short-half-life daughters in secular equilibrium, is presented. Intake assumes inhalation of Class-Y particles with $1 \mu \mathrm{m}$ activity mean aerodynamic diameter (AMAD).

Sources: K. F. Eckerman, A. B. Wolbarst, and A. C. B. Richardson, Limiting Values of Radionuclide Intake and Air Concentration and Dose Conversion Factors for Inhalation, Submersion, and Ingestion, Federal Guidance Report No. 11, EPA Report 520/1-88-020, Washington, D.C., 1988, and K. F. Eckerman and J. C. Ryman, External Exposure to Radionuclides in Air, Water, and Soil, Federal Guidance Report No. 12, EPA Report 402-R-93-081, Washington, D.C., 1993. 
Table 2. Relative total activities of D-38 isotopes

\begin{tabular}{|c|c|c|c|c|c|c|}
\hline \multirow[b]{2}{*}{ Isotope } & \multirow{2}{*}{$\begin{array}{c}\text { Mass } \\
\text { fraction in } \\
\text { mixture } \\
(\%)\end{array}$} & \multirow{2}{*}{$\begin{array}{l}\text { Half-Life } \\
\text { (y) }\end{array}$} & \multirow{2}{*}{$\begin{array}{l}\text { Number of } \\
\text { progeny at } \\
\text { secular } \\
\text { equilibrium }\end{array}$} & \multicolumn{2}{|c|}{$\begin{array}{c}\text { Specific total activity } \\
\left(\mathrm{Bq} \mathrm{g} \mathrm{g}^{-1}\right)^{a}\end{array}$} & \multirow{2}{*}{$\begin{array}{l}\text { Relative } \\
\text { activity in } \\
\text { mixture }\end{array}$} \\
\hline & & & & Isotopic & In mixture & \\
\hline${ }^{234} \mathrm{U}$ & 0.0005 & $2.5 \times 10^{5}$ & 0 & $2.3 \times 10^{8}$ & $1.14 \times 10^{3}$ & 0.0298 \\
\hline${ }^{235} \mathrm{U}$ & 0.25 & $7.0 \times 10^{8}$ & 1 & $1.6 \times 10^{5}$ & $4.0 \times 10^{2}$ & 0.0103 \\
\hline${ }^{238} \mathrm{U}$ & 99.75 & $4.5 \times 10^{9}$ & 2 & $3.7 \times 10^{4}$ & $3.69 \times 10^{4}$ & 0.9599 \\
\hline
\end{tabular}

${ }^{\circ}$ These values include contributions to total activity from each parent isotope listed and its short-lived radioactive progeny at secular equilibrium.

${ }^{b}$ The number of significant figures shown are those considered appropriate for use in the calculation of $h_{\mathrm{E}, \mathrm{D}-38}$, which was then rounded.

$$
\begin{aligned}
h_{\mathrm{E}, \mathrm{D}-38}= & \sum_{i} f_{i, \mathrm{D}-38} h_{\mathrm{E}, \mathrm{i}} \\
= & f_{234, \mathrm{D}-38} h_{\mathrm{E}, 234}+f_{235, \mathrm{D}-38} h_{\mathrm{E}, 235}+f_{238, \mathrm{D}-38} h_{\mathrm{E}, 238} \\
= & {[(0.0298)(0.10)} \\
& \quad+(0.0103)(22.2) \\
& +(0.9599)(3.22)] \mathrm{mrem} / \mathrm{h} \operatorname{per} \mu \mathrm{Ci} / \mathrm{cm}^{2} \\
h_{\mathrm{E}, \mathrm{D}-38}= & 3.32 \mathrm{mrem} / \mathrm{h} \text { per } \mu \mathrm{Ci} / \mathrm{cm}^{2},
\end{aligned}
$$

where $f_{i}$ and $h_{\mathrm{E}, i}$ are the relative contribution to total activity and the dose rate factor, respectively, for the uranium isotope indicated by $i$. This corresponds to a dose rate per unit activity of $1.5 \times 10^{-8} \mathrm{mrem} / \mathrm{h}$ per $\mathrm{dpm} / 100 \mathrm{~cm}^{2}$, given that $1 \mu \mathrm{Ci}=2.22 \times 10^{6} \mathrm{dpm}$.

Oralloy is a mixture of those isotopes found in natural uranium after it has been highly enriched in the ${ }^{235} \mathrm{U}$ isotope by gaseous diffusion. The distribution of uranium isotopes by mass in Oralloy is approximately $93 \%{ }^{235} \mathrm{U}, 6 \%{ }^{238} \mathrm{U}$, and $1 \%{ }^{234} \mathrm{U}$. Although only $1 \%$ by mass, ${ }^{234} \mathrm{U}$ contributes about $94 \%$ of the total radioactivity in Oralloy because of its relatively short half-life (see Table 3 ). The external dose rate factor for Oralloy on surfaces is determined as the activity-weighted sum of dose rate factors for each uranium isotope and its progeny in the mixture. The resulting value of $h_{\mathrm{E}}$ for Oralloy is $1.44 \mathrm{mrem} / \mathrm{h}$ per $\mu \mathrm{Ci} / \mathrm{cm}^{2}$ : 


$$
\begin{aligned}
h_{\mathrm{E}, \mathrm{Oy}}= & \sum_{i} f_{i, \mathrm{Oy}} h_{\mathrm{E}, \mathrm{i}} \\
= & f_{234, \mathrm{Oy}} h_{\mathrm{E}, 234}+f_{235, \mathrm{Oy}} h_{\mathrm{E}, 235}+f_{238, \mathrm{Oy}} h_{\mathrm{E}, 238} \\
= & {[(0.9386)(0.10)} \\
& +(0.0605)(22.2) \\
& \quad+(0.00091)(3.22)] \mathrm{mrem} / \mathrm{h} \text { per } \mu \mathrm{Ci} / \mathrm{cm}^{2} \\
h_{\mathrm{E}, \mathrm{Oy}}= & 1.44 \mathrm{mrem} / \mathrm{h} \text { per } \mu \mathrm{Ci} / \mathrm{cm}^{2} .
\end{aligned}
$$

\begin{tabular}{|c|c|c|c|c|c|c|}
\hline \multirow[b]{2}{*}{ Isotope } & \multirow{2}{*}{$\begin{array}{c}\text { Mass } \\
\text { fraction in } \\
\text { mixture } \\
(\%)\end{array}$} & \multirow{2}{*}{$\begin{array}{l}\text { Half-Life } \\
(y)\end{array}$} & \multirow{2}{*}{$\begin{array}{l}\text { Number of } \\
\text { progeny at } \\
\text { secular } \\
\text { equilibrium }\end{array}$} & \multicolumn{2}{|c|}{$\begin{array}{l}\text { Specific total activity } \\
\left(\mathrm{Bq} \mathrm{g}^{-1}\right)\end{array}$} & \multirow{2}{*}{$\begin{array}{l}\text { Relative } \\
\text { activity in } \\
\text { mixture }\end{array}$} \\
\hline & & & & Isotopic & In mixture & \\
\hline${ }^{234} \mathrm{U}$ & 1 & $2.5 \times 10^{5}$ & 0 & $2.3 \times 10^{8}$ & $2.3 \times 10^{6}$ & 0.9386 \\
\hline${ }^{235} \mathrm{U}$ & 93 & $7.0 \times 10^{8}$ & 1 & $1.6 \times 10^{5}$ & $1.5 \times 10^{5}$ & 0.0605 \\
\hline${ }^{238} U$ & 6 & $4.5 \times 10^{9}$ & 2 & $3.7 \times 10^{4}$ & $2.2 \times 10^{3}$ & $9.1 \times 10^{-4}$ \\
\hline
\end{tabular}

This corresponds to a dose rate per unit activity of $6.5 \times 10^{-9} \mathrm{mrem} / \mathrm{h}$ per dpm$/ 100 \mathrm{~cm}^{2}$.

Table 3. Relative total activities of Oralloy isotopes

These values include contributions to total activity from each parent isotope listed and its short-lived radioactive progeny at secular equilibrium.

${ }^{b}$ The number of significant figures shown are those considered appropriate for use in the calculation of $h_{\mathrm{E}, \text { oy}}$, which was then rounded.

\section{INTERNAL DOSE RATES FROM URANIUM-CONTAMINATED SURFACES}

Uranium on surfaces disturbed by mechanical action (work activities, air currents, etc.) can become resuspended and entrained in air. Respirable particles can then be inhaled, resulting in internal dose commitment to the worker. The measure of the degree of resuspension of particles from a contaminated surface is the resuspension factor $K$, defined as the steady-state ratio of activity concentration $\chi$ in air to the activity concentration $C_{\mathrm{A}}$ on the surface: 


$$
K=\frac{\chi}{C_{\mathrm{A}}} .
$$

Units of $\chi$ are typically in $\mu \mathrm{Ci} / \mathrm{m}^{3}$, and for $C_{\mathrm{A}}, \mu \mathrm{Ci} / \mathrm{m}^{2}$, so that $K$ has units of $\mathrm{m}^{-1}$. A resuspension factor of $1 \times 10^{-6} \mathrm{~m}^{-1}$ is considered in the Health Physics Manual of Good Practices for Uranium Facilities to be "appropriate ... for average work situations and general surface contamination and routine work activities" [EGG-2530, pg. 5-44]. This value of $K$ appears to be related to removable uranium contamination, although this is not explicitly stated in the Manual of Good Practices. The value of $K$ associated with resuspension from the first $0.01 \mathrm{~m}$ of soil surface is, for comparison, about $1 \times 10^{-8} \mathrm{~m}^{-1}$ [NUREG/CR-3332, pp. 5-30 through 5-33]. A resuspension factor of zero is, therefore, assumed in this analysis for fixed contamination, and a factor of $1 \times 10^{-6} \mathrm{~m}^{-1}$ is assumed for removable contamination. Thus, fixed contamination with no removable component presents only an external exposure hazard, whereas fixed contamination with a removable contamination component presents both an internal and an external exposure hazard. The upper limit of internal exposure hazard corresponds to the air activity concentration associated with the $1,000 \mathrm{dpm} / 100 \mathrm{~cm}^{2}\left(4.5 \times 10^{-2} \mu \mathrm{Ci} \mathrm{m}^{-2}\right)$ removable contamination limit for a Radiological Area. This activity concentration, found from Equation 4 and $K=1 \times 10^{-6} \mathrm{~m}^{-1}$, is $4.5 \times 10^{-8} \mu \mathrm{Ci} \mathrm{m}{ }^{-3}$.

Estimates of committed dose equivalent per unit intake are found in Federal Guidance Report No. 11 [FGR 11], which includes exposure-to-dose conversion factors for general use in assessing average individual committed doses. These factors are also available in a computer program, DFINT, v. $4.1^{1}$, which is available from the authors of FGR 11.

Dose factors for integrated exposure to radionuclides in air are derived using conventions of ICRP Publication 26 [ICRP 26]. The committed effective dose equivalent per unit intake $h_{\mathrm{E}, 50}$ is given by

$$
h_{\mathrm{E}, 50}=\sum w_{\mathrm{T}} h_{\mathrm{T}, 50}
$$

using the weighting factors $w_{\mathrm{T}}$ of ICRP Publication 26, where $h_{\mathrm{T}, 50}$ is the committed dose equivalent $H_{\mathrm{T}, 50}$ in tissue $\mathrm{T}$ per unit intake. Values of $h_{\mathrm{E}, 50}$ are given in Table 1 for inhalation of Class-Y uranium particles with 1.0- $\mu \mathrm{m}$ activity mean aerodynamic diameter (AMAD), which is considered here as the limiting case.

The committed effective dose equivalent per unit intake of D-38 is the activity-weighted sum of $h_{\mathrm{E}, 50}$ values for ${ }^{234} \mathrm{U},{ }^{235} \mathrm{U}$ (with its short-half-life daughter, ${ }^{231} \mathrm{Th}$ ), and for ${ }^{238} \mathrm{U}$ (along

${ }^{1}$ DFINT, v. 4.1, A Code to Preview the Dosimetric Data of ICRP Publication 30, Parts $I-4,01992$ by K. F. Eckerman. 
with its short-half-life progeny, ${ }^{234} \mathrm{Th}$ and ${ }^{234 \mathrm{~m}} \mathrm{~Pa}$ ). The resulting value of $h_{\mathrm{E}, 50}$ for $\mathrm{D}-38$ is $1.18 \times 10^{5} \mathrm{mrem} / \mu \mathrm{Ci}$ :

$$
\begin{aligned}
h_{\mathrm{E}, 50(\mathrm{D}-38)}= & \sum_{i} f_{i, \mathrm{D}-38} h_{\mathrm{E}, 50(\mathrm{i})} \\
= & f_{234, \mathrm{D}-38} h_{\mathrm{E}, 50(234)}+f_{235, \mathrm{D}-38} h_{\mathrm{E}, 50(235)}+f_{238, \mathrm{D}-38} h_{\mathrm{E}, 50(238)} \\
= & {\left[(0.0298)\left(1.33 \times 10^{5}\right)\right.} \\
& +(0.0103)\left(1.23 \times 10^{5}\right) \\
& \left.+(0.9599)\left(1.18 \times 10^{5}\right)\right] \mathrm{mrem} / \mu \mathrm{Ci}
\end{aligned}
$$

where the $h_{\mathrm{E}, 50(i)}$ are the committed effective dose equivalents per unit intake for the uranium isotopes indicated by $i$.

The committed effective dose equivalent per unit intake of Oralloy is found similarly to be $1.32 \times 10^{5} \mathrm{mrem} / \mu \mathrm{Ci}$ :

$$
\begin{aligned}
& h_{\mathrm{E}, 50(\mathrm{Oy})}=\sum_{i} f_{i, \mathrm{Oy}} h_{\mathrm{E}, 50(\mathrm{i})} \\
& =f_{234, \mathrm{Oy}} h_{\mathrm{E}, 50(234)}+f_{235, \mathrm{Oy}} h_{\mathrm{E}, 50(235)}+f_{238, \mathrm{Oy}} h_{\mathrm{E}, 50(238)} \\
& =\left[(0.9386)\left(1.33 \times 10^{5}\right)\right. \\
& +(0.0605)\left(1.23 \times 10^{5}\right) \\
& \left.+(0.0009)\left(1.18 \times 10^{5}\right)\right] \mathrm{mrem} / \mu \mathrm{Ci} \\
& h_{\mathrm{E}, 50(\mathrm{Oy})}=1.32 \times 10^{5} \mathrm{mrem} / \mu \mathrm{Ci} \text {. }
\end{aligned}
$$

The committed effective dose equivalent $H_{\mathrm{E}, \text { so (L) }}$ resulting in a work year from exposure to airborne uranium present as a result of resuspension at the $1,000 \mathrm{dpm} / 100 \mathrm{~cm}^{2}$ removable contamination limit for a Radiological Area is the product of the committed effective dose equivalent $h_{\mathrm{E}, 50}$ per unit intake, the airborne activity concentration $C_{\mathrm{A}}=$ $4.5 \times 10^{-8} \mu \mathrm{Ci} \mathrm{m}^{-3}$, and the volume $V$ of air breathed in a work year. The breathing volume given by ICRP [ICRP 23, p. 346] for $8 \mathrm{~h}$ working at "Light Activity" is $9,600 \mathrm{~L}\left(9.6 \mathrm{~m}^{3}\right)$, so that (for $1,760 \mathrm{~h}$ in a work year) $V=2,112 \mathrm{~m}^{3}$, and

$$
\begin{aligned}
H_{\mathrm{E}, 50(\mathrm{~L})} & =C_{\mathrm{A}} V h_{\mathrm{E}, 50}=\left(4.5 \times 10^{-8} \mu \mathrm{Ci} \mathrm{m}^{-3}\right)\left(2,112 \mathrm{~m}^{3}\right) h_{\mathrm{E}, 50} \\
& =\left(9.5 \times 10^{-5} \mu \mathrm{Ci}\right) h_{\mathrm{E}, 50}
\end{aligned}
$$


Therefore, $H_{\mathrm{E}, \text { s0(L) }}$ for D-38 is $11 \mathrm{mrem}$ and, for Oralloy, $13 \mathrm{mrem}$.

\section{CONTAMINATION GUIDELINE}

A fixed-contamination action level is that level of fixed contamination which corresponds to an annual 100-mrem TEDE. Areas of contamination below the fixedcontamination action level require only routine monitoring, posting to alert personnel of the contamination, and administrative control and are not subject to more extensive monitoring, posting, and control requirements designated by $10 \mathrm{CFR} 835$ for Radiological Areas. Fixed uranium contamination with a removable component at the $1,000 \mathrm{dpm} / 100 \mathrm{~cm}^{2}$ limit for a Radiological Area is used as the basis for establishing the action level for uranium.

Additional assumptions used in deriving the uranium fixed-contamination action level are as follows:

(1) Contamination is uniformly distributed and concentrated at the surface being monitored;

(2) The person receiving the exposure remains standing over the area of contamination for the period of exposure;

(3) The period of exposure is one working year $(1,760 \mathrm{~h})$;

(4) Exposure is from a mixture of uranium isotopes between those of D-38 and Oralloy and from their associated decay products, as described in the previous sections.

The annual limit (for purposes of determining the fixed-contamination action level) of dose equivalent received from sources external to the body is the difference between 100 mrem TEDE and the committed effective dose equivalent. The corresponding limiting external dose rate for $\mathrm{D}-38$ is

$$
\frac{(100-11) \mathrm{mrem}}{1,760 \mathrm{~h}}=5.1 \times 10^{-2} \mathrm{mrem} \mathrm{h}^{-1}
$$

and, for Oralloy,

$$
\frac{(100-13) \mathrm{mrem}}{1,760 \mathrm{~h}}=4.9 \times 10^{-2} \mathrm{mrem} \mathrm{h}^{-1}
$$

The ratio of the limiting external dose equivalent rate of Equation 9 and the dose equivalent rate per unit uranium activity, from Equation 2, yields the fixed-contamination action level for D-38. The ratio of Equation 10 with Equation 3 provides the equivalent 
fixed-contamination action level for Oralloy. Table 4 shows fixed-contamination action levels for both D-38 and Oralloy. The action level of $3.4 \times 10^{6} \mathrm{dpm} / 100 \mathrm{~cm}^{2}$ for depleted uranium contamination is seen to represent the limiting case. A uranium fixed-contamination action level of $3.4 \times 10^{6} \mathrm{dpm} / 100 \mathrm{~cm}^{2}$ is the level on which decisions about monitoring, posting, and control for the area of the contamination should be based if a single action level is desired or if the uranium isotopic ratio of the contamination is unknown.

Table 4. Fixed-contamination action levels for D-38 and Oralloy

\begin{tabular}{ccccc}
\hline Isotopic & $\begin{array}{c}\text { Internal } \\
\text { component } \\
\text { of TEDE } \\
(\mathrm{mrem})\end{array}$ & $\begin{array}{c}\text { Limiting external } \\
\text { dose rate } \\
(\mathrm{mrem} / \mathrm{h})\end{array}$ & $\begin{array}{c}\text { Dose rate per unit } \\
\text { activity }(\mathrm{mrem} / \mathrm{h} \text { per } \\
\left.\mathrm{dpm} / 100 \mathrm{~cm}^{2}\right)\end{array}$ & $\begin{array}{c}\text { Action level } \\
\left(\mathrm{dpm} / 100 \mathrm{~cm}^{2}\right)\end{array}$ \\
\hline D-38 & 11 & $5.1 \times 10^{-2}$ & $1.5 \times 10^{-8}$ & $3.4 \times 10^{6}$ \\
Oralloy & 13 & $4.9 \times 10^{-2}$ & $6.5 \times 10^{-9}$ & $7.5 \times 10^{6}$ \\
\hline
\end{tabular}

\section{CONCLUSIONS}

The TEDE from fixed uranium contamination with a removable contamination component up to the radioactivity value which defines a Radiological Area has been derived through an evaluation of the potential for both internal and external exposures. The committed effective dose equivalent associated with exposure for a work year to removable surface contamination of $1,000 \mathrm{dpm} / 100 \mathrm{~cm}^{2}$ is $11 \mathrm{mrem}$ for D-38 and $13 \mathrm{mrem}$ for Oralloy. External dose rates of $5.1 \times 10^{-2} \mathrm{mrem} / \mathrm{h}$ for D-38 and $4.9 \times 10^{-2} \mathrm{mrem} / \mathrm{h}$ for Oralloy, combined with committed effective dose equivalents from the removable contamination, correspond to an annual 100-mrem TEDE. Effective dose equivalent rates from unit activities of contamination for external exposure are $1.5 \times 10^{-8} \mathrm{mrem} / \mathrm{h}$ per dpm/100 $\mathrm{cm}^{2}$ for D-38 and $6.5 \times 10^{-9} \mathrm{mrem} / \mathrm{h}$ per $\mathrm{dpm} / 100 \mathrm{~cm}^{2}$ for Oralloy. Values for fixed uranium surface contamination, with a removable contamination component up to $1,000 \mathrm{dpm} / 100 \mathrm{~cm}^{2}$, that correspond to an annual TEDE of $100 \mathrm{mrem}$ are, therefore, $3.4 \times 10^{6} \mathrm{dpm} / 100 \mathrm{~cm}^{2}$ for D-38 and $7.5 \times 10^{6} \mathrm{dpm} / 100 \mathrm{~cm}^{2}$ for Oralloy.

A uranium fixed-contamination action level of $3.4 \times 10^{6} \mathrm{dpm} / 100 \mathrm{~cm}^{2}$ is suggested if a single action level is desired or if the uranium isotopic ratios are not known. This is the fixed contamination level below which only routine monitoring, posting to alert personnel of the contamination, and administrative control are required, rather than the more extensive requirements for monitoring, posting, and control designated by 10CFR 835 for Radiological Areas. 


\section{REFERENCES}

10 CFR 835

EGG-2530

FGR 11

FGR 12

ICRP 23

ICRP 26
"Occupational Radiation Protection," Code of Federal Regulations, Title 10, Part 835, as codified from Federal Register, Volume 58, Number 238, Washington, D. C., December 1993.

B. L. Rich, S. L. Hinnefeld, C. R. Lagerquist, W. G. Mansfield, L. H. Munson, and E. R. Wagner, Health Physics Manual of Good Practices for Uranium Facilities, Idaho National Engineering Laboratory Report No. EGG-2530 available from U. S. Department of Energy, Office of Scientific and Technical Information, Oak Ridge, Tennessee, 1988.

K. F. Eckerman, A. B. Wolbarst, and A. C. B. Richardson, Limiting Values of Radionuclide Intake and Air Concentration and Dose Conversion Factors for Inhalation, Submersion, and Ingestion, Federal Guidance Report No. 11, EPA Report 520/1-88-020, Washington, D.C., 1988.

K. F. Eckerman and J. C. Ryman, External Exposure to Radionuclides in Air, Water, and Soil, Federal Guidance Report No. 12, EPA Report 402-R-93-081, Washington, D.C., 1993.

International Commission on Radiological Protection, Report of the Task Group on Reference Man, ICRP Publication 23, Pergamon Press, New York, 1971.

International Commission on Radiological Protection, Recommendations of the International Commission on Radiological Protection, ICRP Publication 26, Annals of the ICRP, 1(3), Pergamon Press, New York, 1977.

NUREG/CR-3332 John E. Till and H. Robert Meyer (Eds.), Radiological Assessment, U.S. Nuclear Regulatory Commission, Washington, D.C., 1983. 

ORNL-6913

\section{INTERNAL DISTRIBUTION}

1. J. H. Barker

2-4. J. S. Bogard

5. R. S. Bogard

6. K. J. Brown

7. A. Brynestad

8. G. T. Eagle

9. C.A. England

10. R. N. Hamm

11. G. Hudson
12. D. E. Swenson

13. R. E. Swaja

14. J. E. Turner

15. Laboratory Records

16. Central Research Library

17. ORNL Technical Library, $\mathrm{Y}-12$

18-22. MAD Records Center

\section{EXTERNAL DISTRIBUTION}

23. J. C. Ashley, 8612 Hempstead Drive, Knoxville, TN 37923-5522

24-25. Office of Scientific and Technical Information, U.S. Department of Energy, P.O. Box 62, Oak Ridge, TN 37831 